\title{
Effects of Amrinone on Thrombin-Induced Platelet-Derived Growth Factor-Like Protein Secretion from Endothelial Cells
}

\author{
ROBERT E. SHADDY, JAN E. PAISLEY, AND JOANN C. HANSEN \\ Department of Pediatrics, University of Utah School of Medicine, Salt Lake City. Utah 84132
}

\begin{abstract}
Endothelial cells (EC) secrete plateletderived growth factor (PDGF)-like protein, which is a potent mitogen to smooth muscle and connective tissue cells. The purpose of this study was to determine if amrinone, a phosphodiesterase inhibitor, could inhibit PDGFlike protein secretion on the basis of its ability to increase cAMP. Human umbilical artery endothelial cells (HUAEC) $(n=7)$ were preincubated for $4 \mathrm{~h}$ with amrinone $(10 \mu \mathrm{g} / \mathrm{mL})$ before coincubation with thrombin $(10 \mathrm{IU} / \mathrm{mL})$ and amrinone $(10 \mu \mathrm{g} / \mathrm{mL})$ for $18 \mathrm{~h}$. The supernatant was then assayed for the presence of both PDGF-like protein by using a competitive ${ }^{125}$ I-PDGF radioreceptor inhibition assay, and cAMP by using an RIA. Thrombin-induced PDGF-like protein secretion from HUAEC was significantly inhibited by amrinone $\left(7.8 \pm 1.6 \mathrm{fmol} / 10^{6} \mathrm{EC}\right)$ when compared with thrombin alone $\left(12.1 \pm 2.4 \mathrm{fmol} / 10^{\circ} \mathrm{EC}\right)$ $(p<0.05)$. Amrinone alone had no effect on baseline PDGF-like protein secretion. Amrinone inhibition of thrombin-induced PDGF-like protein secretion was comparable whether amrinone was added to HUAEC 4 or $0 \mathrm{~h}$ before thrombin, and it was dose dependent with a maximal inhibition of $82.7 \%$ by amrinone $(160 \mu \mathrm{g} / \mathrm{mL})$. In contrast, IL-1 $\alpha(10 \mu \mathrm{g} / \mathrm{mL})$ and tumor necrosis factor $(100 \mathrm{ng} / \mathrm{mL})$ induced less secretion of PDGF-like protein from HUAEC, and this secretion was not inhibited by amrinone. Amrinone $(10 \mu \mathrm{g} / \mathrm{mL})$ significantly increased secretion of cAMP from HUAEC from a baseline value of $6.4 \pm 0.4 \mathrm{pmol} / 10^{6} \mathrm{EC}$ to $10.6 \pm 0.1 \mathrm{pmol} / 10^{\circ} \mathrm{EC}(p<0.01)$. We conclude that amrinone inhibits thrombin-induced PDGF-like protein secretion from HUAEC. This ability of amrinone to inhibit thrombin-induced PDGF-like protein secretion from EC is associated with an increase in secretion of CAMP from EC, suggesting that this inhibition is associated with, or mediated through, an increased production of cAMP. (Pediatr Res 30: 351-354, 1991)
\end{abstract}

Abbreviations

EC, endothelial cell

ECCM, endothelial cell conditioned medium

HUAEC, human umbilical artery endothelial cell

PDE, phosphodiesterase

PDGF, platelet-derived growth factor

PDS, plasma-derived serum

TNF, tumor necrosis factor

Received October 8, 1990; accepted May 23, 1991.

Correspondence and reprint requests: Robert E. Shaddy, M.D., Division of Cardiology, Primary Children's Medical Center, 100 North Medical Drive, Salt Lake City, UT 84113.
Pulmonary vascular hypertension, atherosclerosis, and posttransplant accelerated graft arteriosclerosis are major causes of morbidity and mortality in both adults and children. A major component of the pathophysiology of all of these processes is smooth muscle and connective tissue proliferation (1-4). PDGF is a serum mitogen that causes proliferation of smooth muscle and connective tissue cells $(4,5)$. PDGF is found in human serum as a heterodimer of two polypeptide chains (PDGF-A and PDGF-B). PDGF has been implicated in a variety of disease processes by showing the presence of increased PDGF-B-type receptors on vascular smooth muscle cells in atherosclerotic plaques, rejection of transplanted kidneys, and chronic synovitis of rheumatoid arthritis (6). PDGF gene expression is also increased in human atherosclerotic plaques (7). PDGF-like protein is produced by EC, smooth muscle cells, activated macrophages, and mitogen-stimulated fibroblasts (5). Production of PDGFlike protein from cultured EC is stimulated by many factors, including thrombin, IL-1, and TNF $(8,9)$. Work from this laboratory has also shown that $T$ cells are capable of inducing PDGF-like protein from umbilical artery EC (10). The agents currently known to inhibit release of PDGF-like protein from EC include modified LDL, basic fibroblast growth factor, and agents that increase cAMP (isoproterenol, norepinephrine, and forskolin) (11-13). PDE III inhibitors also increase cAMP by inhibition of cAMP degradation. Amrinone is a selective PDE III inhibitor with positive inotropic, chronotropic, and vasodilatory properties (14). We hypothesized that amrinone, through its ability to increase CAMP, may also have utility in regulating PDGF-like protein secretion from EC. The purpose of this study was to investigate the inhibitory potential of amrinone on thrombin-induced PDGF-like protein secretion from HUAEC.

\section{MATERIALS AND METHODS}

HUAEC culture. Umbilical cords were obtained on a daily basis from a busy labor and delivery department of a local hospital. HUAEC were cultured as previously described by our laboratory (15). Briefly, a 3.5 or 5 French umbilical vessel catheter was inserted into one of the umbilical arteries and the vessel was flushed with physiologic saline until free of blood, infused with $0.2 \%$ collagenase, and incubated for $20 \mathrm{~min}$ in $5 \%$ $\mathrm{CO}_{2}-95 \%$ air at $37^{\circ} \mathrm{C}$. The EC aspirated from the cord were resuspended in complete EC medium: M199 containing $25 \mathrm{mM}$ $N$-2-hydroxyethylpiperazine- $N^{\prime}$-2-ethanesulfonic acid buffer, supplemented with L-glutamine $(2 \mathrm{mM})$, penicillin $(100 \mathrm{IU} / \mathrm{mL})$, streptomycin $(100 \mu \mathrm{g} / \mathrm{mL})$, and $20 \%$ pooled human serum. The EC were then pooled from several cords and plated onto $0.2 \%$ gelatin-coated dishes. These cells reached tight confluence within 3 to $5 \mathrm{~d}$. The medium was changed every $3 \mathrm{rd}$ d. All HUAEC used in this experiment were primary cultures. EC identity was verified by the characteristic "cobblestone" morphology under phase-contrast light microscopy and by demonstration of factor VIII-von Willebrand factor antigen by direct immunofluores- 
cence with fluorescein-conjugated anti-von Willebrand factor antibody (16).

$3 T 3$ cell culture. $3 T 3$ cells generously provided by Dr. Martin Rechsteiner of the University of Utah Department of Biochemistry were grown in $75-\mathrm{cm}^{2}$ tissue culture flasks (Falcon Becton Dickinson Labware, Lincoln Park, NJ) and maintained in complete 3T3 cell medium containing 90\% Dulbecco's modified Eagle medium (Sigma Chemical Co., St. Louis, MO) and 10\% FCS (Hyclone, Logan, UT). Medium was changed twice weekly, and the cells were passed in subculture 1:3 upon reaching confluence. Samples of the cells were also frozen in liquid nitrogen for subsequent use.

Generation of ECCM. Because serum contains PDGF, all HUAEC monolayers were incubated for $4 \mathrm{~h}$ in $1 \%$ PDS medium before pre- and coincubations, which were also performed in EC medium containing $1 \%$ PDS. PDS was prepared as previously described (8). Whole blood from healthy, normal donors was drawn into precooled syringes with $3.8 \%$ sodium citrate, and cell-free plasma was then recalcified with $1 \mathrm{M} \mathrm{CaCl}_{2}$ (1:50), followed by incubation at $37^{\circ} \mathrm{C}$ for $2 \mathrm{~h}$ and centrifugation at $25000 \times g$ at $4^{\circ} \mathrm{C}$ for $20 \mathrm{~min}$. The PDS was then filtered $(0.22$ $\mu \mathrm{m}$ pore size), divided into samples, and stored at $-70^{\circ} \mathrm{C}$ until use. To induce PDGF-like protein secretion, HUAEC were incubated with thrombin $(10 \mathrm{IU} / \mathrm{mL})$ for $18 \mathrm{~h}$ as previously described (10). HUAEC were also incubated with IL-1 $\alpha$ (R \& D Systems, Minneapolis, MN) $(10 \mu \mathrm{g} / \mathrm{mL})$ and TNF (generously provided by Cetus Corp., Emeryville, CA) (100 ng/mL). Amrinone (a generous gift of Winthrop Pharmaceuticals, New York City, NY) was added to the HUAEC either 4 or $0 \mathrm{~h}$ before the addition of thrombin. Because we detected no difference between 4- and 0 -h preincubation of amrinone with thrombin, all studies with IL- 1 and TNF were performed with amrinone simultaneously added to the HUAEC. After an 18-h incubation in $5 \%$ $\mathrm{CO}_{2}-95 \%$ air at $37^{\circ} \mathrm{C}$, the supernatant from the HUAEC monolayers was removed, centrifuged at $1100 \mathrm{rpm}$ for $10 \mathrm{~min}$ to remove all cellular debris, and then assayed immediately for the presence of PDGF-like protein by the assay described below. Background PDGF-like protein secretion was determined by assaying the supernatant from HUAEC incubated for $18 \mathrm{~h}$ in $1 \%$ PDS alone. The HUAEC were evaluated by phase-contrast light microscopy for the ability to exclude trypan blue to estimate cell death.

$P D G F$-like protein secretion from HUAEC. ECCM was assayed for the presence of PDGF-like protein by a ${ }^{125}$ I-PDGF (Dupont, Boston, MA) competitive radioreceptor binding assay (17). Before the study, 24-well dishes of confluent 3T3 cells were incubated in serum-free 3T3 cell medium. The dishes were then placed in an ice tray, and the 3T3 cells were washed once with ice-cold binding medium [Dulbecco's modified Eagle medium containing $0.22 \% \mathrm{NaHCO}_{3}$ and BSA $\left.(2 \mathrm{mg} / \mathrm{mL})\right]$. Then, $400 \mu \mathrm{L}$ of either serum-free 3T3 medium (control), $50 \mathrm{ng}$ of unlabeled PDGF (to assess nonspecific binding), or various ECCM were added to each well, and the dishes were incubated at $4^{\circ} \mathrm{C}$ with gentle agitation $(150 \mathrm{rpm})$ for $2 \mathrm{~h}$. After this incubation, the medium on the cells was aspirated and discarded, and the cells were washed once with ice-cold binding medium. Each well then received $0.4 \mathrm{ng}$ of ${ }^{125} \mathrm{I}-\mathrm{PDGF}$, and the dishes were incubated again at $4^{\circ} \mathrm{C}$ with gentle agitation $(150 \mathrm{rpm})$ for $2 \mathrm{~h}$. After this second incubation, the supernatant and two washes were collected and the 3 T 3 cells were lysed with $1 \%$ Triton X-100. The supernatant, wash, and cell lysate were counted separately in a Beckman 4000 gamma counter. The amount of PDGF-like protein present under experimental conditions in ECCM was determined by the percentage of inhibition of maximal ${ }^{125} \mathrm{I}$ PDGF binding to the EC and was expressed as fmol/10 $10^{6}$ cells of PDGF-like protein secreted. Maximal ${ }^{125}$ I-PDGF binding was determined by ${ }^{125}$ I-PDGF presence in the cell lysate fraction of $3 \mathrm{~T} 3$ cells after a 2 -h incubation with serum-free $3 \mathrm{~T} 3$ medium (control). Nonspecific binding was determined by the percentage of binding of maximal ${ }^{125}$ I-PDGF binding to 3 T3 cells after a 2- $h$ incubation with a 100-fold excess of cold PDGF. Initial experiments were performed in triplicate, and dose-response experiments were performed in duplicate. To account for radioactive decay, a 1-ng sample of ${ }^{125}$ I-PDGF was counted separately with each experiment to determine counts/ng of ${ }^{125}$ I-PDGF.

Preliminary studies were done to determine binding characteristics of ${ }^{125}$ I-PDGF to the 3T3 cells. Standard curves were obtained with ${ }^{125}$-PDGF $(0.05-0.4 \mathrm{ng} /$ well $)$ and 100 -fold excess PDGF to determine amounts of specific and nonspecific binding. Nonspecific binding was $13.9 \pm 1.8 \%$.

cAMP secretion from $H U A E C$. Confluent HUAEC monolayers in $25-\mathrm{cm}^{2}$ flasks were incubated with $1 \%$ PDS (control) or amrinone $(10 \mu \mathrm{g} / \mathrm{mL})$ for $18 \mathrm{~h}$ at $37^{\circ} \mathrm{C}$. After the incubation, the flasks were chilled on ice, the medium was aspirated from the cells, boiled for $5 \mathrm{~min}$, and centrifuged, and the supernatant was frozen at $-70^{\circ} \mathrm{C}$ for cAMP assay (18). Measurement of cAMP in supernatants of EC was performed by RIA, with ${ }^{125} \mathrm{I}$-cAMP tracer (Amersham Corp., Arlington Heights, IL).

Statistical analysis. Comparisons between different experimental conditions were made using a paired $t$ test. Values with $p<0.05$ were considered statistically significant. All data is expressed as mean \pm SEM.

\section{RESULTS}

PDGF-like protein secretion was significantly inhibited when HUAEC were preincubated with amrinone $4 \mathrm{~h}$ before coincubation with thrombin for $18 \mathrm{~h}\left(7.8 \pm 1.6 \mathrm{fmol} / 10^{6} \mathrm{EC}\right)$ compared with thrombin alone $\left(12.1 \pm 2.4 \mathrm{fmol} / 10^{6} \mathrm{EC}\right)(n=7)$ (Fig. 1). Background PDGF-like protein secretion was $<1 \mathrm{fmol} / 10^{6} \mathrm{EC}$. Amrinone also had no effect on background PDGF-like protein secretion.

Amrinone inhibition of thrombin-induced PDGF-like protein secretion was comparable when amrinone was added to HUAEC either 4 or $0 \mathrm{~h}$ before thrombin. In the 4-h preincubation, amrinone inhibited thrombin-induced PDGF-like protein secretion by $35.5 \%$, whereas, in the 0 -h preincubation, amrinone inhibited thrombin-induced PDGF-like protein secretion by $34.7 \%(n=8)$.

PDGF-like protein secretion from HUAEC coincubated with thrombin and amrinone $(2.5,10,40$, and $160 \mu \mathrm{g} / \mathrm{mL})$ for $18 \mathrm{~h}$ was inhibited in a dose-dependent fashion (Fig. 2). Thrombininduced PDGF-like protein secretion was inhibited $82.7 \%$ by $160 \mu \mathrm{g} / \mathrm{mL}$ of amrinone, $66.7 \%$ by $40 \mu \mathrm{g} / \mathrm{mL}$ of amrinone, $33.3 \%$ by $10 \mu \mathrm{g} / \mathrm{mL}$ of amrinone, and $14.7 \%$ by $2.5 \mu \mathrm{g} / \mathrm{mL}$ of amrinone. Studies were also carried out with $320 \mu \mathrm{g} / \mathrm{mL}$ of amrinone; however, postincubation examination of the HUAEC with trypan blue revealed them to be very shrunken with a significant amount of cell death. Postincubation trypan blue exam of HUAEC in all other studies showed the cells to be viable with minimal trypan blue uptake.

IL- $1 \alpha$ induced secretion of about one half as much PDGF-like

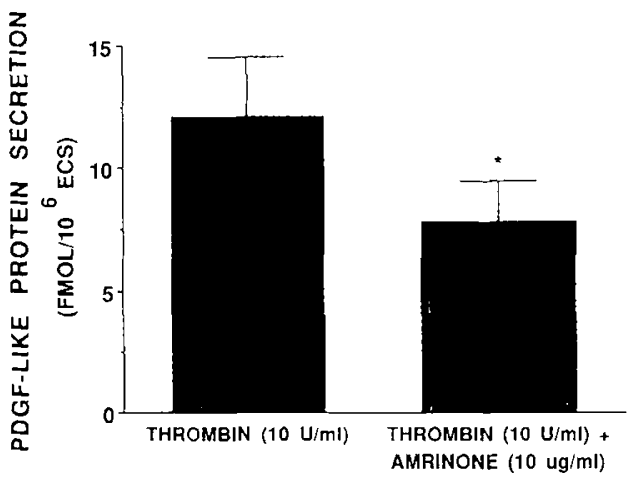

Fig. 1. Inhibition of thrombin-induced PDGF-like protein by amrinone $\left(7.8 \pm 1.6 \mathrm{fmol} / 10^{6} \mathrm{EC}\right)$ compared with thrombin alone $(12.1 \pm$ $\left.2.4 \mathrm{fmol} / 10^{6} \mathrm{EC}\right)\left({ }^{*}, p<0.05\right)$. 


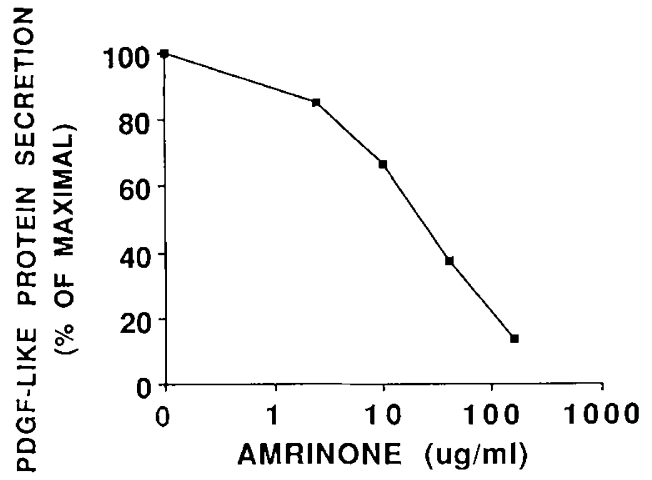

Fig. 2. Dose-response inhibition of thrombin-induced PDGF-like protein by amrinone.

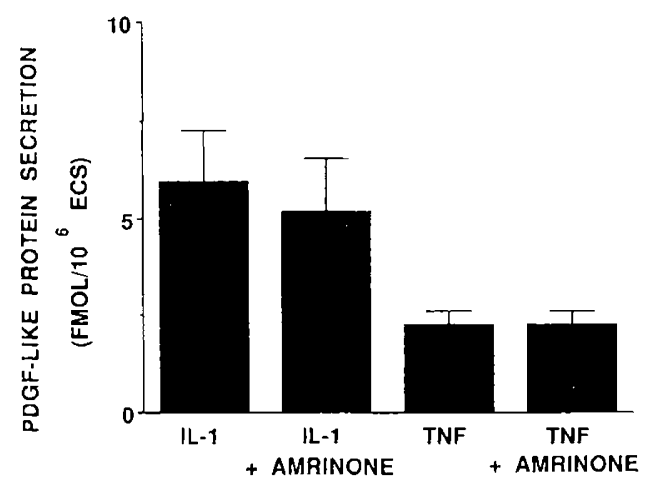

Fig. 3. PDGF-like protein secretion induced by IL-1 $(10 \mu \mathrm{g} / \mathrm{mL})$ and TNF $(100 \mathrm{ng} / \mathrm{mL})$, demonstrating lack of inhibition of PDGF-like protein secretion by amrinone $(10 \mu \mathrm{g} / \mathrm{mL})$.

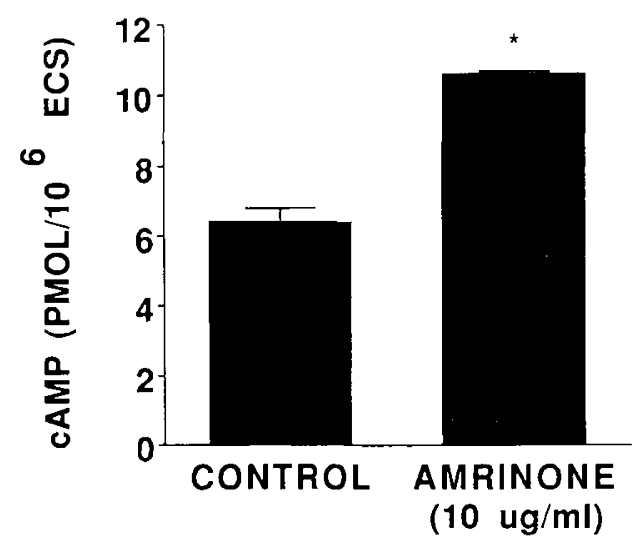

Fig. 4. cAMP production by HUAEC after control incubation with $1 \%$ PDS and after incubation with amrinone $(10 \mu \mathrm{g} / \mathrm{mL})\left({ }^{*}, p<0.05\right)$.

protein from HUAEC $\left(6.0 \pm 1.32 \mathrm{fmol} / 10^{6} \mathrm{EC}\right)$ as thrombin, and this secretion was not significantly inhibited by simultaneous addition of $10 \mu \mathrm{g} / \mathrm{mL}$ of amrinone $\left(5.2 \pm 1.3 \mathrm{fmol} / 10^{6} \mathrm{EC}\right)(n$ $=8$ ) (Fig. 3). TNF induced an even smaller increase in PDGFlike protein secretion from HUAEC $\left(2.3 \pm 0.6 \mathrm{fmol} / 10^{6} \mathrm{EC}\right)$ than was seen with thrombin $(n=8)$. Similarly, this degree of PDGF-like protein secretion was not inhibited by the simultaneous addition of amrinone $(10 \mu \mathrm{g} / \mathrm{mL})$.

Secretion of cAMP from HUAEC after incubation with amrinone for $18 \mathrm{~h}$ was significantly greater $\left(10.6 \pm 0.1 \mathrm{pmol} / 10^{6}\right.$ EC) than control $\left(6.4 \pm 0.7 \mathrm{pmol} / 10^{6} \mathrm{EC}\right)(p<0.05)$ (Fig. 4).

\section{DISCUSSION}

EC secrete PDGF-like protein, which has been identified by biochemical and immunologic criteria (19) and by its ability to competitively block binding of ${ }^{125} \mathrm{I}$-PDGF to its specific cell surface receptor on a variety of different cell types (8). This protein is a potent mitogen for Swiss 3 T3 fibroblasts and smooth muscle cells and is continuously secreted in low levels by healthy, unstimulated EC $(8,20)$. EC can be stimulated to secrete PDGFlike protein by stimuli such as thrombin. IL-1, and TNF. Thrombin is a serine protease generated at sites of vascular injury that (in addition to many other functions) induces cultured $E C$ both to express the $\mathrm{c}$-sis mRNA coding for the B chain of PDGF (21) and to release PDGF-like protein from EC into the culture medium (8). It is speculated that thrombin exerts at least some of its effect on PDGF-like protein by converting molecules present in EC that are not recognized by the PDGF receptor to PDGF-like protein, which is then released (8). The mechanisms of IL-1 and TNF on induction of PDGF-like protein secretion from EC are less clear.

This study shows that amrinone inhibits thrombin-induced PDGF-like protein secretion from HUAEC. This inhibition is dose dependent and does not require HUAEC preincubation with amrinone. Because amrinone increased secretion of CAMP from HUAEC at dosages that increased PDGF-like protein secretion, we hypothesize that amrinone inhibition is associated with, or mediated through, elevation of cAMP levels. Amrinone exerts its effect at the cellular level through inhibition of PDE III, which is found in cardiac muscle, vascular smooth muscle, and human platelets. Inhibition of PDE III leads to decreased degradation of CAMP, subsequent accumulation of CAMP, and enhanced intracellular calcium accumulation (14, 22-24). The concentrations of amrinone required to inhibit PDGF-like protein secretion in our study were very similar to those required to inhibit PDE activity in cultured heart cells from rats (22) and in soluble and particulate fractions of hearts in humans (24). This supports the previous finding that agents which increase cAMP accumulation block endothelial c-sis induction by thrombin (11).

The fact that amrinone had no effect on PDGF-like protein secretion from HUAEC induced by IL-1 or TNF is possibly because of the diminished ability of IL-1 or TNF to induce PDGF-like protein secretion from HUAEC when compared with thrombin. IL-1 is a multifunctional cytokine that has been shown to induce both PDGF-AA and PDGF-B chain ( $\mathrm{c}-$ sis) secretion from EC by mitogenesis assays and Northern blot analysis (25, 26). Hajjar et al. (9) demonstrated the ability of TNF to increase PDGF secretion from cultured EC, also by using mitogenesis assays and Northern blot analysis. These methods are different than the radioreceptor inhibition assay used in this study and thus make it difficult to compare absolute quantities of PDGFlike protein secreted. However, it is possible that the effects of amrinone only become evident when larger quantities of PDGFlike protein are secreted, such as that induced by thrombin. It is also possible that different mechanisms of induction of PDGFlike protein among IL-1, TNF, and thrombin exist, and amrinone only inhibits the mechanism of thrombin-induced PDGF-like protein secretion.

Time-response studies were performed to determine whether EC need to be preincubated with amrinone before coincubation with thrombin to inhibit PDGF-like protein secretion. Previous studies with agents that directly increase CAMP have shown that simultaneous addition of these agents with thrombin to EC effectively inhibited c-sis expression (11). However, because calcium accumulation after amrinone administration takes up to 4 h (22), it was conceivable that simultaneous coincubation of amrinone with thrombin may be less effective in inhibition of PDGF-like protein secretion than 4-h preincubation of EC with amrinone. The fact that there was no difference between amrinone preincubation and simultaneous coincubation with thrombin suggests that the effectiveness of amrinone in blocking thrombin-induced PDGF-like protein secretion is not enhanced by high intracellular calcium concentrations before thrombin administration.

These findings suggest that amrinone may have clinical poten- 
tial for treatment or prevention of disease processes associated with myointimal proliferation. Although catecholamines have previously been shown to inhibit thrombin-induced PDGF-like protein secretion from EC, long-term use causes tachyphylaxis with decreased number of $\beta$-receptors, uncoupling of the receptors from adenylate cyclase, and accelerated cAMP degradation (27). Because of these disadvantages, a medication such as amrinone may have potential for long-term PDGF-like protein inhibition. Oral amrinone has been used clinically in trials to treat chronic congestive heart failure as well as pulmonary hypertension in heart transplant patients awaiting transplantation $(28-30)$. Clinical utility in infants may be limited by the apparent differential effects of amrinone on newborn and adult myocardium $(31,32)$. However, further work is needed to determine in vivo effects of amrinone on the progression of myointimal proliferation.

In conclusion, this study demonstrates that amrinone inhibits thrombin-induced PDGF-like protein secretion from HUAEC and that this inhibition is dose dependent. This suggests a potential clinical role of phosphodiesterase inhibitors such as amrinone in the prevention and treatment of disease processes associated with myointimal proliferation.

Acknowledgments. The authors thank the staff of Labor and Delivery at Cottonwood Hospital for their generous supply of umbilical cords and Kris Sjoblom for manuscript preparation.

\section{REFERENCES}

1. Rabinovitch M 1989 Pulmonary vascular obstructive disease: basic mechanisms and applications to therapy. Curr Opinion Pediatr 1:110-119

2. Johnson DE 1989 The spectrum of coronary artery pathologic findings in human cardiac allografts. Heart Transplant 8:349-359

3. Pahl E, Fricker FJ, Armitage J, Griffith BP, Taylor S, Uretsky BF, Beerman LB, Zuberbuhler JR 1990 Coronary arteriosclerosis in pediatric heart transplant survivors: limitation of long-term survival. J Pediatr 116:177-183

4. Ross R, Faggiotto A, Bowen-Pope D. Raines E 1984 The role of endothelial injury and platelet and macrophage interactions in atherosclerosis. Circulation 70 (suppl lII): $77-82$

5. Ross R, Raines EW, Bowen-Pope DF 1986 The biology of platelet-derived growth factor. Cell 46:155-169

6. Rubin K, Hansson GK, Ronnstrand L, Claesson-Welsh L, Fellstrom B, Tingstrom A, Larsson E, Klareskog L. Heldin C, Terracio L 1988 Induction of B-type receptors for platelet-derived growth factor in vascular inflammation: possible implications for development of vascular proliferative lesions. Lancet 1:1353-1358

7. Barrett TB, Benditt EP 1988 Platelet-derived growth factor gene expression in human atherosclerotic plaques and normal artery wall. Proc Natl Acad Sci USA 85:2810-2814

8. Harlan JM. Thompson PJ. Ross RR, Bowen-Pope DF $1986 \alpha$-Thrombin induces release of platelet-derived growth factor-like molecule(s) by cultured human endothelial cells. Cell Biol 103:1 129-1133

9. Hajjar KA, Hajjar DP, Silverstein RL, Nachman RL 1987 Tumor necrosis factor-mediated release of platelet-derived growth factor from cultured endothelial cells. J Exp Med 166:235-245

10. Shaddy RE, Cowley CG $1990 \mathrm{~T}$ cells induce endothelial cells to secrete platelet-derived growth factor-like protein. Pediatr Res 27:24A (abstr)
11. Daniel TO, Gibbs VC, Milfay DF, Williams LT 1987 Agents that increase cAMP accumulation block endothelial c-sis induction by thrombin and transforming growth factor-B. Biol Chem 262:11893-11896

12. Fox PL, DiCorletto PE 1986 Modified low density lipoproteins suppress production of a platelet-derived growth factor-like protein by cultured endothelial cells. Proc Natl Acad Sci USA 83:4774-4778

13. Kourembanas S. Faller DV 1989 Platelet-derived growth factor production of human umbilical vein endothelial cells is regulated by basic fibroblast growth factor. J Biol Chem 8:4456-4459

14. Levy JH. Baily JM 1989 Amrinone: pharmacokinetics and pharmacodynamics. j Cardiothorac Anesilo 3(suppl 2):10-14

15. Shaddy RE, Mak C, Zimmerman GA 1990 Evidence that the serum of moderate-severely rejecting heart transplant patients induces peripheral blood mononuclear cells to injure endothelial cells. Transplantation 49:1013-1015

16. Jaffe EA, Nachman RL, Becker CG Minick CR 1973 Culture of human endothelial cells derived from umbilical veins. J Clin Invest 52:2745-2756

17. DiCorletto PE, Bowen-Pope DF 1983 Cultured endothelial cells produce a platelet-derived growth factor-like protein. Proc Natl Acad Sci USA 80:1919

18. Cary DA, Mendelsohn FAD 1987 Effect of forskolin, isoproterenol and IBMX on angiotensin converting enzyme and cyclic AMP production by cultured bovine endothelial cells. J Mol Cell Endocrinol 53:103-109

19. DiCorletto PE 1984 Cultured endothelial cells produce multiple growth factors for connective tissue cells. Exp Cell Res 153:167-172

20. Fox PL, DiCorletto PE 1984 Regulation of production of platelet-derived growth factor-like protein by cultured bovine aortic endothelial cells. J Cell Physiol 121:298-308

21. Daniel TO, Gibbs VC, Milfay DF, Garovoy MR, Williams LT 1986 Thrombin stimulates $c$-sis gene expression in microvascular endothelial cells. J Biol Chem 251:9579-9582

22. Hayes JS, Bowling N, Boder GB, Kauffman R 1984 Molecular basis for cardiovascular activities of amrinone and AR-L57. J Pharmacol Exp Ther 230:124-132

23. Weishaar RE, Burrows SD, Kobylarz DC, Quade MM, Evans DB 1986 Multiple molecular forms of cyclic nucleotide phosphodiesterase in cardiac and smooth muscle and in platelets. Biochem Pharmacol 35:787-800

24. Masuoka H, Ito M. Nakano T, Naka M, Tanaka T 1990 Effects of amrinone and enoximone on the subclasses of cyclic AMP phosphodiesterase from human heart and kidney. Cardiol Pharmacol 15:302-307

25. Raines EW, Dower SK, Ross R 1989 Interleukin-1 mitogenic activity for fibroblasts and smooth muscle cells is due to PDGF-AA. Science 243:393396

26. Suzuki H, Shibano K, Okane M, Kono I, Matsui Y, Yamane K, Hashiwagi 1989 Interferon- $\gamma$ modulates messenger RNA levels of $\mathrm{c}$-sis (PDGF-B chain), PDGF-A chain, and IL- $1 \beta$ genes in human vascular endothelial cells. Am J Pathol 134:35-43

27. Wynands JE 1989 Amrinone: is it the inotrope of choice? Cardiol Anesth 3(suppl 2):45-57

28. Dibianco R, Shabetai R, Silverman BE, Leier CV, Benotti JR 1984 Oral amrinone for the treatment of chronic congestive heart failure: results of a multicenter randomized double-blind and placebo-controlled withdrawal study. JACC 4:855-866

29. Deeb GM, Bolling SF, Guynn TP, Nicklas JM 1989 Amrinone versus conventional therapy in pulmonary hypertensive patient awaiting cardiac transplantation. Ann Thorac Surg 48:665-669

30. Deeb GM, Bolling SF 1989. The role of amrinone in potential heart transplant patients with pulmonary hypertension. Cardiol Anesth 3(suppl 2):33-37

31. Klitzner TS, Shapir Y, Ravin R, Friedman WF 1990 The biphasic effect of amrinone on tension development on newborn mammalian myocardium. Pediatr Res 27:144-147

32. Artman M. Kithas PA, Wike JS, Crump DB, Strada SJ 1989 Inotropic responses to cyclic nucleotide phosphodiesterase inhibitors in immature and adult rabbit myocardium. J Cardiovasc Pharmacol 13:146-154 